\title{
GAYA BAHASA REPETISI LAGU KLASIK LAMPUNG DIALEK O DALAM KAJIAN LINGUISTIK ANTROPOLOGIS
}

\author{
REPETITION STYLE LAMPUNG CLASSIC SONG \\ O DIALECT, AN ANTHROPOLIGICAL LINGUSITIK STUDY
}

\author{
Roveneldo \\ Kantor Bahasa Lampung \\ Jalan Beringin II Nomor. 40 Kompleks Gubernuran Telukbetung, Bandarlampung \\ Telepon (0721) 486408, Faksimile (0721) 486407 \\ Ponsel: 08117210380; Pos-el: roveneldo2011@gmail.com
}

Diterima: 12 September 2019; Direvisi: 4 Desember 2019; Disetujui: 4 Desember 2019

DOI https://doi.org/10.26499/mab.v13i2.252

\begin{abstract}
Abstrak
Penelitian ini mendeskripsikan tentang gaya bahasa perulangan, ungkapan dan makna kiasan, dan nilai-nilai luhur dalam lirik lagu klasik Lampung dialek $\mathrm{O}$ yang berjudul sanak aruk 'anak yatim'. Metode penelitian ini menggunakan metode kualitatif deskriptif. Objek penelitian yaitu lagu klasik Lampung ciptaan Supirman yang berjudul sanak aruk 'anak yatim'. Hasil analisis data dapat disimpulkan terdapat gaya bahasa perulangan atau repetisi epizeukis (semacam gaya bahasa, repetisi yang berupa perulangan langsung atas kata yang dipentingkan beberapa kali berturut-turut), dan repetisi simploke (gaya bahasa repitisi yang berupa perulangan pada awal dan akhir beberapa baris atau kalimat berturut-turut). Ungkapan dan makna kiasan yang digunakan dalam lirik lagu ini adalah gaya bahasa perbandingan atau perumpamaan; seperti, ibarat, bak, dan penaka. Penggunaan repetisi memberikan pengaruh cukup kuat terhadap lirik lagu klasik Lampung dialek O seperti makna kesedihan, makna keikhlasan, makna kesetiaan, makna cinta, dan makna perubahan. Nilai-nilai luhur yang terdapat dalam lirik lagu ini adalah pandai memahami rahasia hidup, pandai memahami kehidupan dengan arif, dan mempertinggi budi pekerti.
\end{abstract}

Kata Kunci: gaya bahasa; repetisi; lingguistik antropolinguistik; lagu klasik Lampung

\begin{abstract}
This research describes repetition style found in Lampung classic song and expressions and idioms used in Lampung classic song, O dialect titled Sanak Aruk 'an orphan'. The method used in this research is qualitative-descriptive method and the object of the research is Lampung classic song, titled Sanak Aruk 'an orphan' written by Supirman. Result of the analysis concludes that the repetition style used in the song is epizuekis repetition (a kind of repetition styles repeating the Important words many times in a row) and simploke repetition (repeating the first and the last lyric, either phrase and sentence in a row). The expressions and idioms used in the song is a comparative one, like metaphor, like, and example. The use of repetition strongly effect the lyrics of the Lampung classic song, dialect $O$. It conveys the meaning of sadness, sincere, loyalty, love, and change. The noble values contained in the song are intelligence to understand the life secret, to understand wisdom, and to improve the character.
\end{abstract}

Keywords: language style; repetition; linguistic anthropology; Lampung classic song 


\section{Pendahuluan}

Penggunaan gaya bahasa sering ditemui pada puisi, cerita pendek, wacana, media massa, lirik lagu, dan di banyak tempat lainnya. Gaya bahasa digunakan untuk memudahkan pengungkapan pikiran dalam mendeskripsikan maksud dan tujuan, sehingga relasi makna tersampaikan.

Gaya bahasa yang sering dijumpai pada setiap lagu biasanya menggunakan gaya bahasa perulangan, gaya bahasa yang mengandung perulangan kata atau kelompok kata yang sama berkali-kali. Kata-kata yang terdapat pada lirik lagu klasik Lampung dialek O (LKL) karya Supirman, khususnya lirik lagu yang berjudul sanak aruk 'anak yatim' didominasi dengan pengulangan kata.

LKL dialek $\mathrm{O}$ mengisyaratkan nilainilai luhur yang terkandung di dalamnya. Selain itu, makna yang tersirat di dalam LKL dialek $\mathrm{O}$ tersebut mengisahkan kehidupan sehari-hari. Makna dan isyarat yang ada dalam lagu klasik Lampung dialek $\mathrm{O}$ tersebut mengungkapkan rasa sedih, gembira, duka, cinta, sayang, dan banyak hal tentang cerita di dalam kehidupan.

Memahami sebuah makna, aspek makna berhubungan dengan perasaan, sikap pembicaraan, dengan situasi pembicaraan (Djajasudarma, 2013). Di dalam kehidupan sehari-hari, kita selalu berhubungan dengan perasaan (misalnya sedih, panas, dingin, gembira, jengkel, dll). Senada dengan pendapat tersebut, Abdul Chaer (1995) menjelaskan bahwa makna adalah memahami unsur-unsur makna pada bunyibunyi dan fonem-fonem bahasa. Makna juga memberikan sebuah informasi dan maksud tertentu sehingga makna yang ada di dalam sebuah lagu itu sangat variatif.

LKL adalah ciri khas kesenian beretnis Lampung berdialek O. Kesenian ini memiliki kebudayaan adat istiadat yang disebut pepadun. LKL dialek $\mathrm{O}$ sangat mudah ditemukan dalam bentuk kaset. Berkat inovasi teknologi saat ini yang lebih mutakhir, masyarakat bisa mendengar, melihat gambar, dan teks di layar monitor kesenian ini, seperti dalam bentuk video cakram padat (VCD). Bahkan, pada saat ini, LKL sering didengar dan diputar di stasiun televisi lokal seperti TVRI Lampung, SigerTV, Delta, RadarTV, TegarTV, NetTV, dan RRI Pro4 Bandar lampung dalam acara budaya Lampung setiap hari. Dengan demikian, peran teknologi elektronik saat ini sangat mendukung dan bermanfaat bagi pengembangan kesenian dan untuk memperkenalkan bermacam-macam kebudayaan daerah.

Perkembangan teknologi tersebut tentunya dapat memicu kepopuleran adat istiadat budaya Lampung. Hal itu dapat memudahkan masyarakat untuk mengetahui keunikan kebudayaan Lampung. Masyarakat dapat mengenal, mendengar, dan melihat 
secara langsung teks lagu klasik Lampung dengan baik.

Menelusuri dan memahami sebuah makna LKL dialek O cukup menarik. Karena itu, perlu dilakukan kajian dalam bentuk sebuah penelitian ilmiah supaya objek yang akan diteliti tersingkap dengan tepat.

Rumusan masalah dalam penelitian ini adalah (1) gaya bahasa perulangan apa saja yang terdapat pada lirik lagu yang berjudul sanak aruk 'anak yatim'. ungkapan dan makna kiasan apakah yang digunakan lirik lagu yang berjudul sanak aruk 'anak yatim'. (3) nilai-nilai luhur dalam lirik lagu yang berjudul Sanak Aruk 'anak yatim'.

\section{Landasan Teori}

Pengertian gaya bahasa menurut (Tarigan, 2013) adalah bahasa indah yang digunakan untuk meningkatkan efek dengan jalan memperkenalkan

serta membandingkan suatu benda atau hal tertentu dengan benda atau hal lain yang lebih umum.

Bapak bahasa Keraf dalam (Tarigan, 2013) menjelaskan gaya bahasa mengungkapkan pikiran melalui bahasa secara khas yang memperlihatkan jiwa dan kepribadian penulis (pemakai bahasa). Sebuah gaya bahasa yang baik harus mengandung tiga unsur berikut: kejujuran, sopan-santun, dan menarik.

Keraf dalam (Parwati, 2011:809) mengungkapkan bahwa gaya bahasa perulangan disebut repetisi (pengulangan kata). Repetisi adalah perulangan bunyi, etnis kata, atau bagian kalimat yang dianggap penting untuk memberi tekanan dalam sebuah konteks. Dengan demikian, fungsi repetisi yaitu untuk memberikan penekanan dan sebagai penegas dalam sebuah konteks yang sesuai.

Terdapat dua belas gaya bahasa perulangan yaitu (1) repetisi aliterasi yaitu gaya bahasa repetisi yang berwujud perulangan konsonan yang sama; (2) repetisi asonansi yaitu semacam gaya bahasa repetisi yang berwujud perulangan bunyi vokal yang sama; (3) repetisi antanaklasis yaitu sejenis gaya bahasa repetisi yang berwujud perulangan kata yang sama bunyi dengan makna yang berbeda; (4) repetisi kiasmus yaitu gaya bahasa yang berisikan perulangan dan sekaligus merupakan inversi antara dua kata dalam satu kalimat; (5) repetisi simplok adalah sejenis gaya bahasa repitisi yang berupa perulangan pada awal dan akhir beberapa baris atau kalimat berturut-turut; (6) epizeukis adalah semacam gaya Bahasa repetisi yang berupa perulangan langsung atas kata yang dipentingkan beberapa kali berturut-turut; (7) repetisi tautoles adalah gaya bahasa repetisi yang berupa perulangan atas sebuah kata dalam sebuah 
konstruksi; (8) anafora adalah gaya bahasa repetisi yag berupa perulangan kata pertama pada setiap baris atau setiap kalimat; (9) epistopa adalah semacam gaya bahasa repetisi yang berupa perulangan kata atau frase pada akhir baris atau kalimat berurutan; (10) mesodilopsis adalah repetisi sejenis gaya bahasa perulangan kata atau frase di tengah baris atau beberapa kalimat beruntun; (11) epanalepsis adalah semacam gaya repetisi yang berupa perulangan kata pertama menjadi terakhir dalam klausa atau kalimat; dan (12) anadiplosis adalah sejenis gaya bahasa repetisi di mana kata atau frase terakhir dari suatu klausa atau kalimat menjadi frase pertama dari klausa atau kalimat berikut (Tarigan, 2013).

Keterkaitan gaya bahasa dengan teori linguistik antropologis dalam penelitian ini adalah LKL merupakan salah satu tradisi atau kebudayaan etnis Lampung. Dari masa ke masa, sampai saai ini tradisi LKL masih dijunjung tinggi oleh penuturnya. Menurut para pakar yang berbasis disiplin linguistik, bidang interdisipliner tersebut disebut linguistik antropologi. Bagi Foley dalam (Kartubi, 2017), linguitik antrofologi adalah subbidang linguistik yang memusatkan perhatian dan menempatkan bahasa dalam konteks sosial dan kebudayaan yang lebih luas, yakni perannya dalam menempa dan menopang praktik kebudayaan dan struktur sosial. Oleh karena itu, linguistik antropologi mencari untuk menemukan "makna" di balik penggunaan, salah penggunaan, dan tidak digunakannya bahasa, bentuk bahasa tertentu, register dan style yang berbeda dari bahasa tersebut

Dari uraian di atas, dapat dipahami bahwa linguistik antropologi memandang bahasa melalui sudut pandang kebudayaan untuk menemukan "makna" di balik penggunaan bahasa.

\section{Metode Penelitian}

Metode dalam penelitian ini adalah metode kualitatif yang bersifat deskiptif. Penggunaan metode ini dalam penelitian ini berdasarkan pada ciri-ciri dan sifat-sifat data bahasa apa adanya. Pertimbangan ini sesuai dengan salah satu ciri metode penelitian kualitatif yaitu berlatar alamiah atau sesuai dengan konteks dari suatu keutuhan. Metode ini bertujuan menguraikan makna-makna yang terdapat dalam lagu klasik Lampung dialek O yang berjudul Sanak Aruk 'anak yatim'. Data primer penelitian ini berupa data tulisan yang berupa tuturan kata, frasa, dan kalimat bahasa Lampung dialek $\mathrm{O}$ yang didapatkan melalui teks lagu, catat, dan rekaman.

Selanjutnya, sumber data (data tulis) diperoleh dari VCD (video cakram padat) yang diproduksi Sai Betik Record. Setelah data terkumpul, penulis melakukan pengolahan data lalu mengklasifikasikan 
makna apa saja yang terdapat dalam lirik lagu berbait-bait tersebut. Setelah itu, penulis melakukan analisis dan interpretasi data dengan menggunakan metode agih. Metode agih adalah metode penyajian informal melalui perumusan kata-kata. (Sudaryanto, 2018) menyatakan metode agih adalah metode yang berupa bagian atau unsur dari bahasa objek sasaran penelitian itu sendiri, seperti kata (kata ingkar, preposisi, adverba, dsb), fungsi sintaktis (subjek, objek, predikat, dsb), klausa, silabe kata, titinada, dan lain-lain.

\section{Hasil Dan Pembahasan}

\subsection{Lagu klasik Lampung}

LKL dialek $\mathrm{O}$ adalah salah satu warisan budaya etnis Lampung yang beradat pepadun, begitu juga LKL etnis Lampung yang beradatkan Sai Batin berdialek A. Kedua budaya tersebut memiliki perbedaan dari pengucapan bahasa, irama, dan intonasi dalam melantunkan LKL tersebut.

LKL dialek $\mathrm{O}$ adalah salah satu identitas etnik yang ada di Provinsi Lampung. Kita akan memahami aktivitas LKL jika LKL digunakan sebagai alat ungkap perasaan, gagasan, dan pikiran pada masyarakat pada saat-saat tertentu, mulai dari kegiatan perintang waktu hingga curahan perasaan. Nyanyian LKL memiliki kandungan pesan makna yang meliputi sindiran, nasihat, kritik, petuah, ajaran-ajaran moral, budaya dan norma agama islam. Keindahan susunan kata dalam nyanyian LKL dikemas dalam bahasa simbolis daerah atau alegoris. Pada umumnya, penyanyi LKL tidak mengutarakan secara langsung isi hatinya, tetapi semua disampaikan dengan samar-samar. Begitu juga dengan syair lagu yang berbentuk bahasa lisan atau tulisan, kita dapat memahaminya melalui makna kata-kata yang terdapat dalam lirik lagu tersebut.

Aktivitas sosial LKL muncul dalam acara-acara tertentu seperti jaga damar 'acara bujang gadis; atau memadukan rasa senang terhadap muda mudi', acara begawi 'upacara adat perkawinan; acara besunat 'khitanan', dan acara resmi pemerintah. Terkait dengan penelitian ini, Misthohizzaman (2006) dalam judul tesisnya menganalisis tentang "Gitar Klasik Lampung Musik dan Identitas Masyarakat Tulangbawang" dengan diiringi LKL menyatakan bahwa masyarakat adat pepadun menjadikan gitar menjadi musik klasiknya, dijadikan sebagai hiburan dalam aktivitas pribadi dan aktivitas sosial masyarakat.

Selanjutnya, pembahasan tentang gitar klasik telah dibahas dan disebut oleh beberapa ahli, di antaranya oleh Don Michael Randel dalam (Barmawi, 2017). Kata klasik berasal dari bahasa latin classicus yang lebih jauh berasal dari classisi 
merujuk kepada kelompok masyarakat yang menduduki kasta tertinggi di Roma. Sementara (Banoe, 2003) memberikan batasan klasik dengan 1) keadaan atau kondisi yang mutunya patut dicontoh dan terikat pada tradisi; 2) zaman lampau, priode sebelum zaman romantik; dan 3) gaya musik masa kejayaan Haydn dan Beethoven pada saat mana musik dibakukan dan menjadi panutan periode zaman berikutnya.

Dari uraian di atas, kita dapat memahami mengapa lagu LKL dapat dikategorikan lagu klasik. Hal ini disebabkan lagu ini lirik-lirik lagu ini memakai bahasa Lampung yang berdialek $\mathrm{O}$ dan diiringi oleh gita klasik.

\subsection{Bentuk Gaya Bahasa Repetisi Pada LKL Dialek O Sanak Aruk 'Anak Yatim'}

Pada paragraf pertama ditemukan gaya bahasa repetisi epizeukis. Gaya bahasa ini semacam gaya bahasa yang berupa perulangan langsung atas kata yang dipentingkan beberapa kali berturut-turut, seperti perulangan kata biduk 'perahu'. Hal ini dapat dilihat pada lirik berikut ini.

\section{Talimu Biduk}

Pegat Talimu Biduk

Mu Biduk

'Talimu Perahu

Putus Talimu Perahu

Diri Mu Perahu'

Pada paragraf kedua, ketiga, dan keempat terdapat gaya bahasa repetisi simploke yaitu gaya bahasa berupa perulangan pada awal dan akhir beberapa baris atau kalimat berturut-turut seperti yang terlihat pada lirik berikut ini.

Jamuhang Jak Pangkalan

Jamuhang Jak Pangkalan

'Berlayar Dari Dermaga

Berlayar Dari Dermaga'

Sangun Kak Gadu Tanyo

Sangun Kak Gadu Tanyo

Sanak Aruk Buangan

'Memang Sudah Hanyut

Memang Sudah Hanyut

Anak Yatim Terbuang'

Sangun Kak Gadu Tanyo

Sangun Kak Gadu Tanyo

Sanak Aruk Buangan

'Memang Sudah Hanyut

Memang Sudah Hanyut

Anak Yatim Terbuang'

Pada paragraf lima ditemukan gaya bahasa repetisi epizeukis. Gaya bahasa ini semacam gaya bahasa yang berupa perulangan langsung atas kata yang dipentingkan beberapa kali berturut-turut, seperti perulangan kata buangan 'terbuang' yang dapat dilihat pada lirik berikut ini.

Buangan

Sanak Aruk Buangan

Buangan

'Terbuang

Anak Yatim Terbuang

Terbuang'

Pada paragraf enam, tujuh, dan delapan terdapat gaya bahasa repetisi simploke, gaya bahasa berupa perulangan 
pada awal dan akhir beberapa baris atau kalimat berturut-turut seperti yang terdapat pada lirik berikut ini.

Sangon Mak Ngemek Teduh

Sangon Mak Ngemek Teduh

'Memang Tidak Ada Harapan

Memang Tidak Ada Harapan'

Gelek Kain Serilang

Gelek Kain Serilang

Pakaiku Ngemban Ken Luh

'Habis Kain Selembar

Habis Kain Selembar

Untukku Mengusapkan Air Mata'

Gelek Kain Serilang

Gelek Kain Serilang

Pakaiku Ngemban Ken Luh

'Habis Kain Selembar

Habis Kain Selembar

Untukku Mengusapkan Air Mata'

Pada paragraf sembilan dan sepuluh terdapat dua gaya bahasa yaitu repetisi epizeukis dan repetisi simploke. Gaya bahasa repetisi epizeukis gaya bahasa yang berupa perulangan langsung atas kata yang dipentingkan beberapa kali berturut-turut seperti perulangan kata Niku Tiyuh 'kamu kampung'. Gaya bahasa repetisi simploke berupa gaya bahasa berupa perulangan pada awal dan akhir beberapa baris atau kalimat berturut-turut seperti yang terlihat pada lirik berikut ini.

Niku Tiyuh...

Tepik Pai Niku Tiyuh
Niku Tiyuh...

'Kamu Kampung

Tinggal Lah Kamu Kampung

Kamu Kampung'

Kas Badan Wara Wiri

Kas Badan Wara Wiri

'Bekas Bada Pulang Pergi

Bekas Bada Pulang Pergi'

Pada pragraf sebelas dan dua belas terdapat gaya bahasa repetisi simploke, gaya bahasa berupa perulangan pada awal dan akhir beberapa baris atau kalimat berturutturut seperti yang terlihat pada lirik berikut ini.

Sejo Ngebuang Teduh

Sejo Ngebuang Teduh

Kalau-kalau Wat Bagei

'Ini Membuang Harapan

Ini Membuang Harapan

Mudah-Mudahan Ada Bagian'

Sejo Ngebuang Teduh

Sejo Ngebuang Teduh

Kalau-kalau Wat Bagei

'Ini Membuang Harapan

Ini Membuang Harapan

Mudah-Mudahan Ada Bagian'

Pada paragraf tiga belas, empat belas, dan lima belas terdapat dua gaya bahasa yaitu repetisi epizeukis dan repetisi simploke. Gaya bahasa repetisi epizeukis berupa gaya bahasa perulangan langsung atas kata yang dipentingkan beberapa kali berturut-turut seperti kata perulangan $\mathrm{Di}$ Wai Deres 'Di Air Deras'. Gaya bahasa repetisi simploke berupa gaya bahasa perulangan 
pada awal dan akhir beberapa baris atau kalimat berturut-turut seperti yang terlihat pada lirik berikut ini.

Di Wai Deres...

Belayar Di Wai Deres

Di Wai Deres

Pengayuh Cappak Di Wai

Pengayuh Cappak Di Wai

'Di Air Deras Berlayar

Di Air Deras

Di Air Deras

Sampan Terjatuh Di Air

Sampan Terjatuh Di Air'

Hai Badan Tedes-Tedes

Hai Badan Tedes-Tedes

Dang Malang Mangei Wawai

'Hai Badan Bersabar Sabar

Hai Badan Bersabar Sabar

Walau Susah Nanti Juga Bagus'

Hai Badan Tedes-Tedes

Hai Badan Tedes-Tedes

Dang Malang Mangei Wawai

'Hai Badan Bersabar Sabar

Hai Badan Bersabar Sabar

Walau Susah Nanti Juga Bagus'

Pada paragraf enam belas, tujuh belas, dan delapan belas terdapat dua gaya bahasa yaitu repetisi epizeukis dan repetisi simploke. Gaya bahasa repetisi epizeukis gaya bahasa berupa perulangan langsung atas kata yang dipentingkan beberapa kali berturut-turut seperti perulangan kata Membunyi 'Berbunyi'. Gaya bahasa repetisi simploke berupa gaya bahasa perulangan pada awal dan akhir beberapa baris atau kalimat berturut-turut seperti yang terlihat pada lirik berikut ini.

Membunyi Geduk Subuh Membunyi

Membunyi Tando Ulun Sembahyang

Tando Ulun Sembahyang

'Berbunyi Beduk Subuh Berbunyi

Berbunyi Tanda Orang Sembahyang

Tanda Orang Sembahyang'

Sedih ku Jamo Diri

Sedih ku Jamo Diri

Kapan You Dapok Mulang

'Sedihku Dengan Diri

Sedihku Dengan Diri

Kapan Dia Bisa Pulang'

Sedih ku Jamo Diri

Sedih ku Jamo Diri

Kapan You Dapok Mulang

'Sedihku Dengan Diri

Sedihku Dengan Diri

Kapan Dia Bisa Pulang'

Pada paragraf sembilan belas, dua puluh, dan dua puluh satu terdapat dua gaya bahasa yaitu repetisi epizeukis dan repetisi simploke. Gaya bahasa repetisi epizeukis berupa gaya bahasa perulangan langsung atas kata yang dipentingkan beberapa kali berturut-turut seperti perulangan kata Ngepik Tanggeh 'Tinggalkan Pesan'. Gaya bahasa repetisi simploke berupa gaya bahasa perulangan pada awal dan akhir beberapa baris atau kalimat berturut-turut seperti yang terlihat pada lirik berikut ini.

Ngepik Tanggeh

Sejou Nyak Ngepik Tanggeh

Ngepik Tanggeh

'Tinggalkan Pesan

144 | Mabasan, Vol. 13, No. 2, Desember 2019, hlm. 137-150 p-ISSN: 2085-9554, e-ISSN: 2621-2005 
Ini Saya Meninggalkan Pesan

Tinggalkan Pesan'

Liwat Ahli Pemilei

Liwat Ahli Pemilei

'Melalui Ahli Saudara

Melalui Ahli Saudara'

Direy Ku Gadeu Jaweh

Direy Ku Gadu Jaweh

Lapah Ngebuang Direi

'Diriku Sudah Jauh

Diriku Sudah Jauh

Jalan Membuang Diri'

\subsection{Makna Lagu Klasik Lampung Berjudul Sanak Aruk 'Anak Yatim'.}

Pembahasan makna LKL dengan menganalisis lirik-liriknya. Pembahasan pengulangan bait atau pembaitan tidak diulas. Berikut pembahasan makna-makna dalam LKL.

Talimu Biduk...

'Talimu Perahu'

Pegat Talimeu... Biduk...

'Putus Talimu Perahu'

Mu Biduk..

Diri Mu Perahu'

Jamuhang Jak Pangkalan

'Berlayar Dari Dermaga'

\section{Jamuhang Jak Pangkalan}

'Berlayar Dari Dermaga'

Pada baris pertama pada paragraf pertama, terdapat kalimat Pegat Talimu... Biduk... 'Putus Talimu Perahu'. Kalimat dalam LKL ini mengunakan kata perumpamaan. Kisah lagu dalam bait pertama tersebut bermakna seorang anak yang ditinggalkan oleh ibu atau ayahnya menjadi anak yatim. Awal kalimat yang disuguhkan menceritakan kesedihan seorang anak yang ditinggalkan orang tuanya. Kalimat yang terdapat pada baris keempat seperti Jamuhang Jak Pangkalan Berlayar Dari Dermaga' menceritakan anak tersebut harus berjuang memulai kehidupannya. Memulai dan mencari kehidupan untuk masa depannya. Berusaha kuat tanpa dampingan orang tua. Menjadi anak yang mandiri dan tangguh menghadapi roda kehidupannya.

Pada paragraf pertama hanya dua kalimat yang memiliki arti, sedangkan baris kedua, ketiga, dan kelima hnaya berupa reduplikasi gramatikal kata atau kalimat, yaitu berupa pengulangan kalimat berturutturut dan penekanan makna terhadap kata atau kalimat pada baris pertama dan keempat. Cuplikan video lagu ini berlatar belakang sungai yang besar dan anak yatim yang berdayung sampan. Lirik-lirik lagu pada paragraf ini bermakna pasang surut sebuah perjalanan kehidupan harus dihadapi dengan keiklasan. Lirik-lirik lagunya sebagai berikut.

Sangun Kak Gadu Tanyo...

'Memang Sudah Hanyut'

Sangun Kak Gadu Tanyo ... 'Memang Sudah Hanyut' 
Sanak Aruk Buangan

'Anak Yatim Terbuang'

Buangan

'Terbuang'

Sanak Aruk Buangan

'Anak Yatim Terbuang'

Buangan....

'Terbuang'

Sangon Mak Ngemek Teduh

'Memang Tidak Ada Harapan'

Sangon Mak Ngemek Teduh

'Memang Tidak Ada Harapan'

Paragraf kedua dan ketiga masih ada kesinambungan atau keterkaitan makna dengan paragraf pertama. Hal ini dapat dilihat dengan munculnya Sangun Kak Gadu Tanyo 'Memang Sudah Hanyut' pada baris pertama paragraf kedua. Kalimat tersebut menggunakan kata perumpamaan. Kata hanyut dalam KBBI (2008) bermakna terbawa oleh arus (banjir, ombak, dsb); terbawa mengalir. Dengan demikian, anak yatim tersebut sudah terbawa oleh arus, mengalir seiring dengan perjuangan dalam menemukan sebuah kehidupan. Harapan dan keinginan mudah-mudahan dapat sampai apa yang diharapkan.

Selanjutnya, pada baris ketiga paragraf kedua terdapat kalimat Sanak Aruk Buangan 'Anak Yatim Terbuang'. Kalimat tersebut bermakna anak yatim yang terbuang, tidak berguna atau anak yang tidak diperhatikan oleh sanak saudaranya. Orang selalu berpikir bahwa nasibnya tidak semujur anak-anak yang lain.

Kemudian, pada baris ketujuh paragraf ketiga, terdapat kalimat Sangon Mak Ngemek Teduh Memang Tidak Ada Harapan'. Kalimat tersebut bermakna anak yatim tersebut dalam kehidupannya tidak mempunyai harapan dalam kehidupannya. Masa depannya tidak bagus dan suram karena banyak kekurangan pada dirinya. Tidak ada saudara yang dapar membantunya sehingga masyarakat menilainya atau memandangnya dengan 'sebelah mata'.

Pada paragraf kedua dan ketiga hanya kalimat pada baris pertama dan ketujuh yang memiliki makna. Pada baris kedua, ketiga, keempat, kelima, keenam, dan kedelapan, hanya berupa perulangan kata atau kalimat. Penekanan atau penegasan terhadap paragraf kedua dan ketiga terdapat pada baris kedua dan ketujuh.

Gelek Kain Serilang...

'Kain Selembar'

Gelek Kain Serilang...

'Habis Kain Selembar'

Pakaiku Ngemban Ken Luh...

'Untukku Mengusapkan Air Mata'

Pada paragraf keempat terdapat tiga kalimat dalam bahasa Lampung. Pada baris pertama dan kedua terdapat pengulangan kalimat dengan menggunakan kata perumpamaan, seperti kalimat Gelek Kain Serilang 'habis kain semeter sampai satu 
meter setengah'. Kain tersebut untuk menghapus air mata. kalimat tersebut mengisyaratkan betapa lama dan banyaknya kesedihan dalam kehidupan seseorang sampai menghabiskan kain yang cukup lebar untuk menghapus air mata. Kalimat tersebut juga bermakna untaian kesedihan yang tak kunjung padam atau berhenti, kemalangan selalu menghampiri. Baris ketiga hanya kalimat yang menerangkan kalimat pada baris sebelumnya. Hal ini bisa dilihat pada kalimat berikut 'Pakaiku Ngemban Ken Luh Untukku Mengusapkan dan membuang Air Mata'. Kain tersebut objek untuk menghapus kesedihan.

Niku Tiyuh... Tepik Pai Niku Tiyuh... Kamu Kampung Tinggal Lah Kamu Kampung'

Niku Tiyuh... Kas Badan Wara Wiri

Kamu Kampung Tinggal Lah Kamu Kampung'

Kas Badan Wara Wiri...

'Bekas Badan Pulang Pergi'

Sejo Ngebuang Teduh...

'Ini Membuang Harapan'

Sejo Ngebuang Teduh...

'Ini Membuang Harapan'

\section{Kalau-kalau Wat Bagei}

Mudah-Mudahan Ada Bagian

Selanjutnya, paragraf lima dan paragraf enam mempunyai kesinambungan karena kedua paragraf ini memiliki makna berkesinambungan. Kalimat pada dua paragraf tersebut bermakna seseorang yang harus meniggalkan kampung halamannya, tempat badan dilahirkan. Sebelum merantau, seseorang haraus berpamitan kepada orangorang lain. Walaupun rasa hati sendih dan berat meninggalkan kampung, tempat badan hilir mudik, merantau harus dilakukan. Hal itu dilakukan demi cita-cita untuk memperjuangkan kehidupan yang lebih baik. Harapan tersebut banyak dimimpikan orang. Harapan itulah yang bisa menguatkan diri dan menguatkan semangat untuk menggapai cita-cita.

Di Wai Deres...

Belayar Di Wai Deres

'Di Air Deras Berlayar

Di Air Deras'

Di Wai Deres...

'Di Air Deras'

Pengayuh Cappak Di Wai...

'Sampan Terjatuh Di air'

Pengayuh Cappak Di Wai...

'Sampan Terjatuh Di Air'

Hai Badan Tedes-Tedes...

'Hai Badan Bersabar Sabar'

Hai Badan Tedes-Tedes...

'Hai Badan Bersabar Sabar'

Dang Malang Mangei Wawai

'Walau Susah Nanti Juga Bagus'

Paragraf ketujuh dan kedelapan menggunakan kata perumpamaan dan kalimat perulangan. Kalimat yang diulangulang untuk menegaskan sebuah makna yang dimaksudkan. Kalimat pada dua paragraf ini bermakna seseorang yang merantau ke 
negeri orang penuh dengan tantangan. Tantangan yang dihadapi di antaranya mengarugi sungai yang deras. Untuk mengatasi hambatan dan rintangan tersebut, dibutuhkan tenaga dan pikiran yang kuat. Dengan ketekunan, keuletan, dan kesabaran, hasil yang baik akan didapatkan. Doa dan usaha tidak akan mengingkari sebuah hasil yang baik. Diperlukan juga ketekunan dan doa yang iklas. Pada akhirnya, hasil yang diinginkan akan tercapai.

\section{Membunyi Geduk Subuh Membunyi.. 'Berbunyi Beduk Subuh Berbunyi'}

mbunyi Tando Ulun Sembahyang...

'Berbunyi Tanda Orang Sembahyang'

Tando Ulun Sembahyang...

Tanda Orang Sembahyang,

Kalimat pada paragraf sembilan di atas mengisyarakat sebuah makna bahwa selain berusaha kita harus beribadah. Kepada Allah Swt kita berdoa dan meminta apa yang kita inginkan. Jangan tinggalkan salat lima waktu. Ketika azan sudah dikumandangkan, bersegeralah salat. Hidup tidak ada artinya jika kita tidak ibadah kepada-Nya sebagai bekal di akhirat nanti, walaupun yang menentukan kehidupan kita adalah Allah Swt.

Sedih ku Jamo Diri... 'Sedihku Dengan Diri'

Sedih ku Jamo Diri... 'Sedihku Dengan Diri'
'Kapan Dia Bisa Pulang'

Pada paragraf kesepuluh tergambar sebuah kesedihan sepanjang kehidupan ketika merantau ke tempat orang. Selalu teringat tempat diri dilahirkan yaitu kampung halaman. Rindu ingin pulang, berharap melihat saudara-saudara di 'kampung'. Ingin memperlihatkan diri bahwa diri sudah cukup berhasil. Ingin berziarah ke tempat beristirahat terakhir orang yang tua yang sudah lama meninggal. Masa-masa kecil yang penuh kenangan tidak dapat dilupakan. Tidak pernah berhenti dalam berusaha dan mencari sebuah kehidupan dan selalu berangan-angan agar cita-cita dapat tercapai.

Ngepik Tanggeh...

'Tinggalkan Pesan'

Sejou Nyak Ngepik Tanggeh

'Ini Saya Meninggalkan Pesan'

Ngepik Tanggeh

'Tinggalkan Pesan'

Liwat Ahli Pemilei

Melalui Ahli Saudara'

Liwat Ahli Pemilei

'Melalui Ahli Saudara'

Direy Ku Gadeu Jaweh...

'Diriku Sudah Jauh'

Direy Ku Gadu Jaweh...

'Diriku Sudah Jauh'

Lapah Ngebuang Direi...

'Jalan Membuang Diri' 
paragraf kesebelas, kedua belas, dan ketiga belas tidak dapat terpisahkan karena masih ada runutan makna dan keterkaitan makna di antara kalimat-kalimat tersebut. Kalimatkalimat tersebut bermakna sang anak yatim berpesan kepada semua saudara yang ada di kampung, baik saudara yang dekat maupun yang jauh tanpa terkecuali: Saya berjuang untuk kehidupan. Saya memperjuangkan kehidupan yang lebih baik di negeri yang sangat jauh. Saya telah membuang diri untuk kebahagiaan dunia dan akhirat. Doa restu sangat diharapkan semoga hidupnya tidak mudah rapuh dan selalu semangat dalam dalam mengarungi kehidupan nanti.

\section{Penutup}

Terdapat dua gaya bahasa dalam penggunaan lirik lagu ini yaitu repetisi epizeukis dan repetisi simploke. Gaya bahasa repetisi epizeukis berupa gaya bahasa perulangan langsung atas kata yang dipentingkan beberapa kali berturut-turut, seperti kata biduk 'perahu', niku tiuh 'kamu kampung', di wai deres 'di air deras', membunyi 'berbunyi', ngepik tanggeh 'tinggalkan pesan'. Kata-kata itu berulang kali muncul untuk menegaskan ungkapan maksud dan tujuan seperti nilai-nilai luhur yang telah diungkapkan di atas. Selanjutnya, repetisi simploke berupa gaya bahasa perulangan pada awal dan akhir beberapa baris atau kalimat berturut-turut. Gaya bahasa ini, sebagai ciri khas lirik lagu klasik Lampung dialek $\mathrm{O}$.

Temuan penelitian ini memiliki pesan nilai ajaran yang cukup baik bagi kita. Ajaran nilai-nilai luhur tersebut di antaranya kita harus berusaha dan bangkit dari keterpurukan dan kesedihan. Kita pantang untuk meminta-minta bahkan berpangku tangan. Walaupun berstatus anak yatim, kita harus kuat menerima kesusahan dan kenyataan hidup. Kita harus berusaha dan berjuang walaupun banyak rintangan yang dilalui. Kita tidak boleh berputus asa atau berpatah arang. Perjalanan kehidupan sangat menantang untuk dilewati. Dengan kesabaran dan ketekunan, kita bisa hidup dengan lebih baik.

Peneliti berharap adanya penelitian berikutnya tentang lagu klasik Lampung dialek A karena penelitian seperti ini jarang dilakukan.

\section{Daftar Pustaka}

Banoe, Pono. (2003). Kamus Musik. Yogyakarta: Kanisius.

Barmawi, Erizal. (2017). Prosiding Kegiatan Ilmiah Tingkat Nasional Kearifan Lokal Dalam Dinamika Masyarakat Multikultural. Lembaga Penelitian dan Pengabdian Kepada Masyarakat. UNILA.

Chaer, Abdul. (1995). Pengantar Semantik Bahasa Indonesia. Jakarta: PT Rineka Cipta. 
Djajasudarma, T. Fatimah. (2013). Semantik; Relasi Makna, Paradigmatik, Sintagmatik, dan Derivasional. Bandung: PT Refika Aditama.

Kartubi. (2017). Linguistik Antropologi: Disiplin Ilmu Yang Termarjinalisasi Pada Program Studi Linguistik. Jurnal Antropologi: Isu-Isu Sosial Budaya. Volume 19 (1) hlm 1--10.

Misthohizzaman. (2006). Gitar Klasik Lampung Musik dan Identitas Masyarakat Tulang Bawang. Tesis Untuk Memenuhi Persyaratan Mencapai Derajat Sarjana S-2. Yogyakarta: Sekolah Pascasarjana Universitas Gadjah Mada.

Parwati, Edin. (2011). Kohesi Leksikal Repetisi Pada Wacana "Wayang Durangpo" Dalam Surat Kabar Harian Jawa Pos Edisi Februari-April 2010. Jurnal Artikulasi. Volume 12 No 2 hal 809-810.

Sudaryanto. (2018). Metode dan Aneka Teknik Analisis Bahasa. Pengantar Penelitian Wahana Kebudayaan secara Linguistik. Sanata Dharma University Press.

Supirman. (2019). Gitar Klasik Lampung Dialek O Ciptaan Supirman, Vokal Supirman. Dalam https://youtu.be/ICn0XYI_X5k (diakses pada 05 November 2019.

Tarigan, Guntur Henry. (2013). Pengajaran Gaya Bahasa. Bandung: Penerbit Angkasa.

Tim Penyusun. (2008). Kamus Besar Bahasa Indonesia. Jakarta: Departemen Pendidikan Nasional. Penerbit PT Gramedia Pustaka Utama. .

Wijaya, Putu Dewa I. dkk. (2011). Semantik Teori dan Analisis. Yuma Pustaka. 